\title{
Two new species of the millipede family Glomeridae from Vietnam (Diplopoda: Glomerida)
}

\author{
Ава новых вида диплопод семейства Glomeridae из Вьетнама \\ (Diplopoda: Glomerida)
}

\author{
Sergei I. Golovatch, Irina I. Semenyuk \\ С. И. Головач, И. И. Семенюк
}

Institute for Problems of Ecology and Evolution, Russian Academy of Sciences, Leninsky prospekt 33, Moscow 119071, Russia; E-mail: sgolovatch@yandex.ru

Институт проблем экологии и эволюции РАН, Ленинский проспект 33, Москва 119071, Россия.

\begin{abstract}
KEY WORDS: Glomerida, Rhopalomeris, Hyleoglomeris, taxonomy, new species, Vietnam.
КЛЮЧЕВЫЕ СЛОВА: Glomerida, Rhopalomeris, Hyleoglomeris, таксономия, новый вид, Вьетнам.
\end{abstract}

ABSTRACT. Two new species are described from forest litter in central and southern Vietnam, respectively: Rhopalomeris variegata sp.n. and Hyleoglomeris cattienensis sp.n. Both differ from congeners primarily by peculiar colour patterns. A key is given to all four presently known species of the genus Rhopalomeris Verhoeff, 1906.

РЕЗЮМЕ. Из лесной подстилки соответственно в Центральном и Южном Вьетнаме описаны два новых вида: Rhopalomeris variegata sp.n. и Hyleoglomeris cattienensis sp.n. Они отличаются от остальных видов в своих родах, прежде всего, особенностями окраски. Дан ключ для всех четырех ныне известных видов рода Rhopalomeris Verhoeff, 1906.

\section{Introduction}

The basically Holarctic millipede family Glomeridae, as well as the order Glomerida where it belongs, both are long known to show two major diversification centres, one in the Mediterranean area and the other in Southeast Asia [Minelli, 2015]. These two regions share only one genus, Hyleoglomeris Verhoeff, 1910, the largest and most widespread in the whole order. This genus currently contains over 100 species which range from the Balkans in the west, through Anatolia, the Caucasus and Central Asia, to China, Korea, Japan and Taiwan in the east, and the Philippines and Sulawesi, Indonesia in the southeast, with the bulk of species diversity being confined to southeastern and eastern Asia [Golovatch, 2015]. In contrast, Rhopalomeris Verhoeff, 1906, is a small Oriental genus which comprises only three species ranging from Malaysia and Myanmar in the south, through Thailand, to northern Vietnam in the north [Golovatch et al., 2011]. The nomenclature of both these genera has become stabilized only quite recently [Golovatch et al., $2011]$.
The present note adds one new species each to Rhopalomeris and Hyleoglomeris, both collected by the second author in forest litter in Vietnam. The types are deposited in the collection of the Zoological Museum, State University of Moscow, Russia (ZMUM + acquisition number).

\section{Rhopalomeris variegata sp.n.}

Figs $1-7$.

MATERIAL. HOLOTYPE $0^{7}$ (ZMUM $\rho 3485$ ), Vietnam, Gia Lai Prov., Kon Chu Rang Nature Reserve, $14^{\circ} 30^{\prime} 54^{\prime \prime} \mathrm{N}, 108^{\circ} 32^{\prime} 47^{\prime \prime} \mathrm{E}$, ca $1000 \mathrm{~m}$ a.s.l., mixed tropical forest in flood-plain, leaf litter, 05.2016, leg. I.I. Semenyuk.

PARATYPES: 3 OP (ZMUM $\rho 3486$ ), same data, together with holotype.

NAME. To emphasize the highly characteristic, variegated coloration; adjective.

DIAGNOSIS. This new species differs clearly from all three other species of the genus, R. carnifex (Pocock, 1889), the type-species from the Malay Peninsula and adjacent archipelagos within Malaysia, Myanmar and southern Thailand, $R$. monacha Silvestri, 1917, from Perak State, Western Malaysia, and $R$. tonkinensis Silvestri, 1917, from Mount Mau Son, Lang Son Province, northern Vietnam, primarily by the peculiar, variegated colour pattern, from $R$. carnifex, the sole other congener known also from the $\sigma^{7}$ sex, additionally by a considerably shorter and less strongly curved antennomere 6, and a smaller and lower central lobe of the telopod syncoxite [Silvestri, 1917; Golovatch et al., 2011]. See also Key below.

DESCRIPTION. Length of holotype ca $15 \mathrm{~mm}$, width (maximum on tergum 2) ca $7.0 \mathrm{~mm}$; length of paratypes ca $16\left(\sigma^{7}\right)$ or $17-18 \mathrm{~mm}(+)$, width on tergum 2 ca $7.5-8.0 \mathrm{~mm}\left(\sigma^{7},+\right)$. Body rather uniformly dark, brown and grey-yellowish, only ocelli blackish. Antennae mostly dark marbled brown to brown, only antennomere 8 pallid. Head largely brown, only labrum and mid-dorsal parts lighter, grey-yellowish. Dorsal pattern not too strongly contrasting, but clearly variegated 

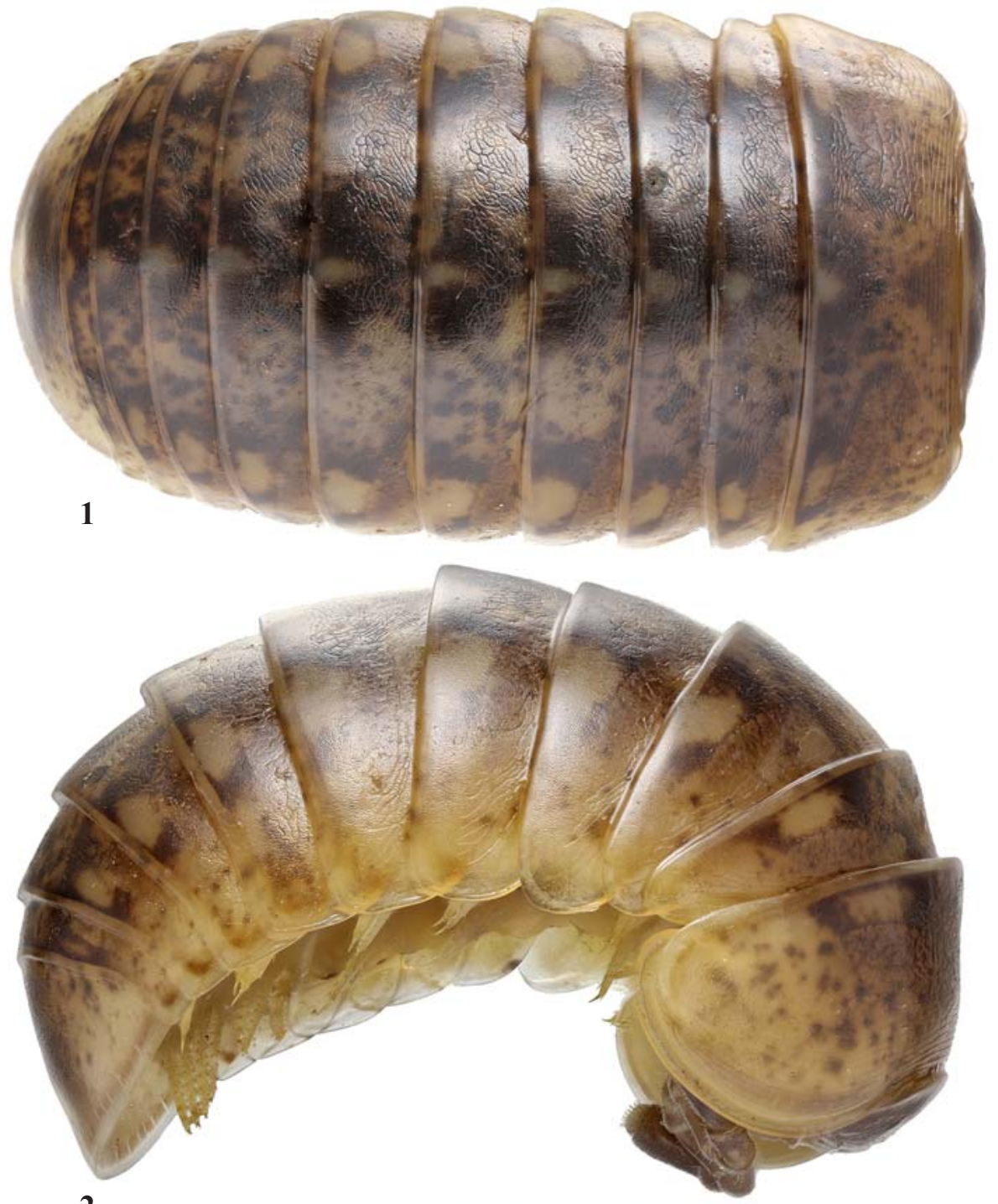

2

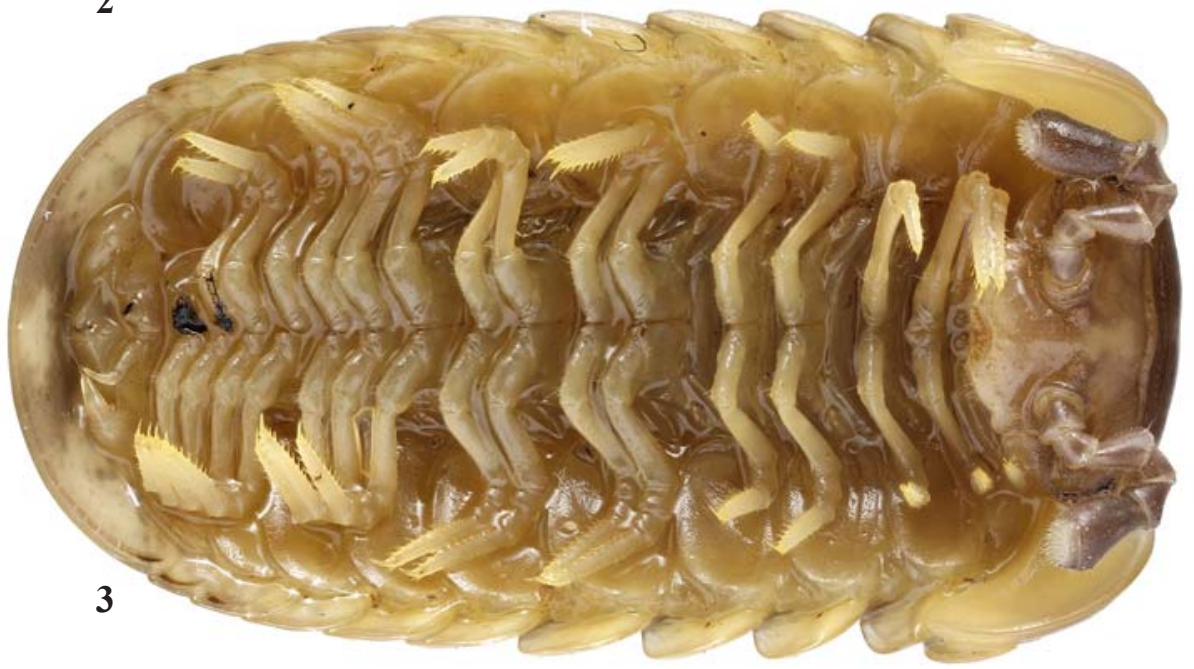

Figs 1-3. Habitus of Rhopalomeris variegata sp.n., O' holotype: 1 - dorsal view; 2 - lateral view; 3 - ventral view. Pictures by K. Makarov, taken not to scale.

Рис. 1-3. Общий вид Rhopalomeris variegata sp.n., голотип О': 1 - сверху; 2 —сбоку; 3 - снизу. Фотографии К. Макарова, снято без масштаба. 
(Figs 1-3): collum with a marbled yellow-brownish, oblong, central spot only slightly separated along lighter anterior and posterior margins, as well as from both lighter lateral ends; postcollum terga with an axial series of light, small, subtriangular spots at caudal margin; a paramedian pair of larger, transversely ovoid, dorsolateral, sometimes strongly mottled spots; and another paramedical pair of similarly large, transversely ovoid, sometimes likewise strongly mottled, sublateral spots. Anal shield (= pygidium) with a large, light, central, more or less rounded spot reaching a similarly light caudal margin; sides also light, but mottled. Venter and legs entirely light grey-yellowish.

Tergal tegument very finely leathery, moderately shining. Ocelli 8+1, convex, completely translucent. Tömösváry's organ transverse-oval, ca 1.4 times wider than long. Antennomere 6 rather short, ca 2.0 times as long as high, dorsal margin as usual, only slightly curved (Figs 3 4). Disk of antennomere 8 beset with numerous, small, sensory cones (Figs 3-4). Collum with two transverse striae. Tergum 2 with a narrow hyposchism not reaching behind caudal tergal margin; 8-10 superficial transverse striae: three starting below schism, two level with, all others (3-5) above schism, with 6-8 crossing the dorsum. Anal shield regularly rounded at caudal margin.

$\sigma^{7}$ leg 17 (Fig. 5) strongly reduced, with a high, rather regularly rounded, outer coxal lobe; telopodite 4segmented, with only one strong apical spine. $\sigma^{7}$ leg 18 (Fig. 6) less strongly reduced, with an ogival syncoxital notch; telopodite also 4-segmented, tarsus with one apical spine.

$\sigma^{7}$ legs 19 , or telopods (Fig. 7), very strongly incrassate, with a relatively low, rounded, central, syncoxital lobe flanked by two poorly setose horns, each latter about twice as high as syncoxital lobe and crowned by a very small, finger-shaped, rounded lobule. Prefemur anteriorly with a typically long trichostele distoventrally. Femur distoventrally with a small anterior trichostele and a large posterior outgrowth, the latter set at ca $120^{\circ}$ to femur and bearing a membranous apical sac folded anteriad. Tibia distoventrally with a strong anterior seta and a rather large posterior outgrowth, the latter also bearing a membranous apical sac folded anteriad, as well as a distinct, round, parabasal tubercle on caudal face. Tarsus rather strongly curved, subacuminate apically.

REMARKS. The diagnosis of Rhopalomeris as formulated in Minelli [2015] is not very exact, as it considers only the characters of the type-species, $R$. carnifex. Antennomere 6 in most congeners is actually typical of Glomeridae, less strongly curved, although the numerous sensory cones on antennomere 8 are indeed striking and clearly apomorphous. In fact, the antennae in Rhopalomeris are the same as in the sympatric genus Peplomeris Silvestri, 1917, whereas the conformation of $\sigma^{7}$ legs $17-19$ is the same as in the largely sympatric genus Hyleoglomeris (see also below).

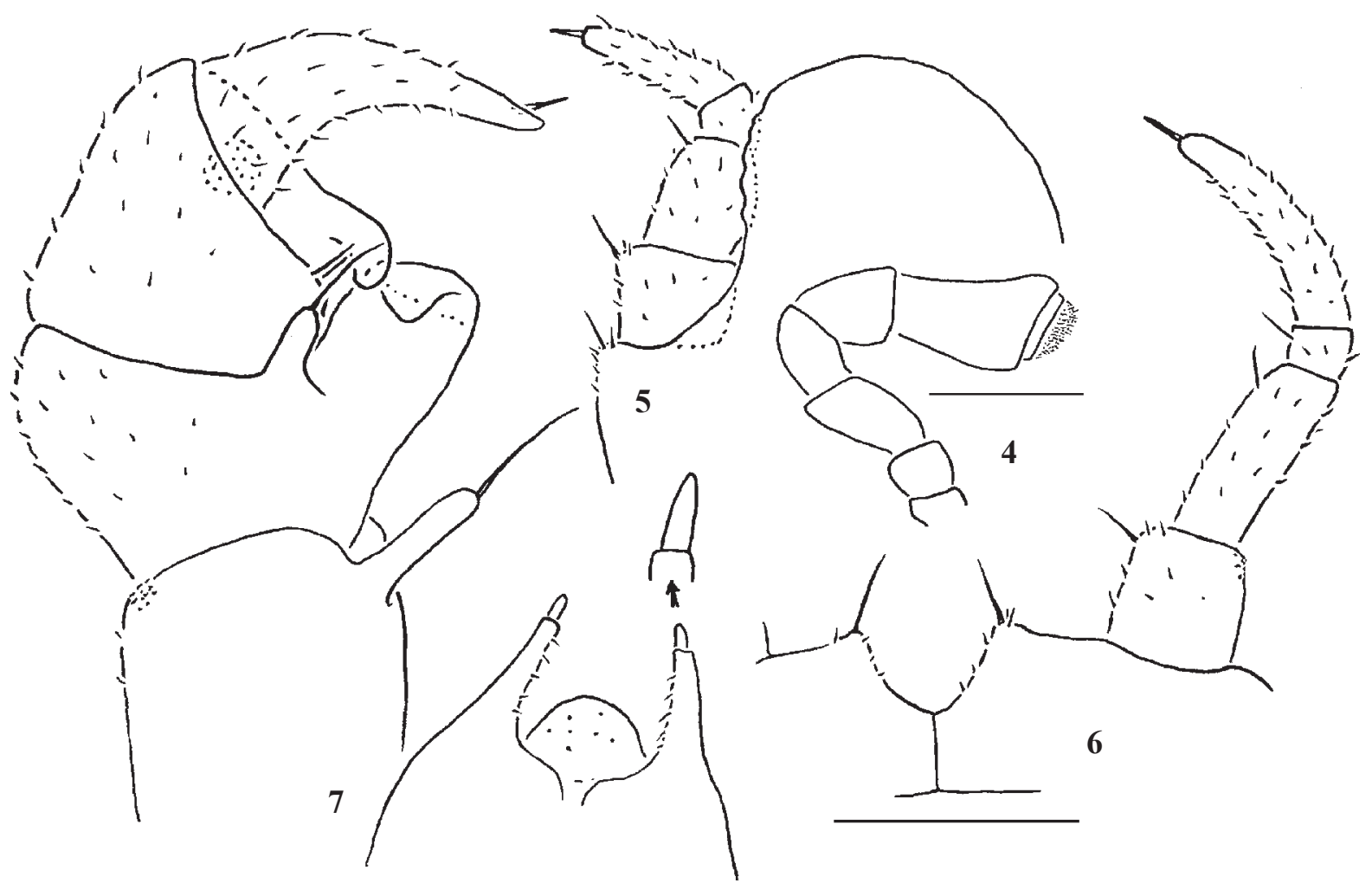

Figs 4-7. Rhopalomeris variegata sp.n., $\sigma^{7}$ holotype: 4 - antenna, lateral view; 5 - right leg 17, anterior view; 6 - right leg 18, anterior view; 7 - left telopod, anterior view. Scale bars: $4-1.0 \mathrm{~mm}$; $5-7-0.5 \mathrm{~mm}$.

Рис. 4-7. Rhopalomeris variegata sp.n., голотип О?: 4 - антенна, сбоку; 5 - правая нога 17, спереди; 6 - правая нога 18, спереди; 7 - левый телопод, спереди. Масштаб: $4-1,0$ мм; 5-7 - 0,5 мм. 
The following key to Rhopalomeris spp. can be proposed to incorporate the new species.

1(2) Antennomere 6 usually remarkably long and strongly curved, its dorsal margin very distinctly concave. Dorsum mostly dark, pattern not variegated, lateral margins of terga and/or caudal margin of anal shield sometimes carmine. Central lobe of telopod syncoxite clearly higher than lateral horns, each of the latter with a tiny filament on top. Much of Malay Peninsula R. carnifex

2(1) Antennomere 6 usually shorter and at most only faintly curved, its dorsal margin at most only slightly concave (Figs 3 \& 4). Dorsum generally either dark or light, pattern sometimes variegated, but lateral margins of terga never carmine. Central lobe of telopod syncoxite (when known) clearly lower than lateral horns, each of the latter without filament on top

3(4) Body relatively small, ca $12 \mathrm{~mm}$ long and $6 \mathrm{~mm}$ wide. Head, collum and tergum 2 light yellowish, body mostly blackish thereafter, but a light, rather broad, axial stripe continuing even onto anal shield. Antennomere 6 short, only 1.8-1.9 times as long as high, its dorsal margin straight. Perak State, Western Malaysia ...... R. monacha

4(3) Body larger, at least $15 \mathrm{~mm}$ long and $7 \mathrm{~mm}$ wide. Entire dorsum mostly dark. Antennomere 6 somewhat longer, its dorsal margin slightly concave. Vietnam.

5(6) Body ca $20 \mathrm{~mm}$ long and $11 \mathrm{~mm}$ wide (+). Coloration of dorsum mostly blackish, not variegated. Antennomere 6 ca 2.1-2.2 times as long as high. Hyposchism field smaller, far from reaching caudal margin of tergum 2 in lateral view, carrying only two striae. Mount Mau Son, Lang Son Province ............................................ R. tonkinensis

6(5) Body ca $15-18 \mathrm{~mm}$ long and 7-8 $\mathrm{mm}$ wide ( $\sigma^{7}$, + $)$. Coloration of dorsum mostly brown, very clearly variegated (Figs 1-3). Antennomere 6 slightly shorter, ca 2.0 time as long as high (Figs 3-4). Hyposchism field larger, reaching caudal margin of tergum 2 in lateral view, carrying three striae (Fig. 2). Kon Chu Rang Nature Reserve, Gia Lai Province ................ R. variegata sp.n.

\section{Hyleoglomeris cattienensis sp.n.} Figs 8-13

Hyleoglomeris sp. - Golovatch et al., 2011: 80; Golovatch et al., 2013: 202.

MATERIAL. HOLOTYPE O (ZMUM 03487 ), Vietnam, Dong Nai Prov., Cat Tien National Park, tropical, monsoon, lowland forest, near caves, leaf litter, 01.2012, leg. I.I. Semenyuk.

PARATYPES: 6 +P (ZMUM $\rho 3488$ ), same data, together with holotype.

NAME. To emphasize the provenance from the Cat Tien National Park; adjective.

DIAGNOSIS. This new species differs from all other, very numerous species of the genus primarily by its characteristic, highly vivid colour pattern. From apparently the most similar, and geographically perhaps the closest, $H$. robusta Attems, 1938, from Peak Lang Bian, Dalat Province, southern Vietnam, the new species differs in the lateral parts of tergum 2 and most of the anal shield being light, while the transverse striae on tergum 2 are less numerous (6-7, of which 3-4 cross the dorsum, versus 9-10, of which 7-8 cross the dorsum) [Attems, 1938; Golovatch et al., 2006].

DESCRIPTION. Length of holotype ca $16 \mathrm{~mm}$, width (maximum on tergum 2) ca $7.0 \mathrm{~mm}$; length of paratypes ca 17-18 mm ( 9 ), width on tergum 2 ca 7.0 $8.0 \mathrm{~mm}\left(\sigma^{\gamma},+\right)$. Body mostly dark, blackish brown with contrasting grey-yellowish or yellowish markings, ocelli also blackish. Antennae mostly dark marbled brown to blackish, only antennomere 8 light. Head largely brown, only labrum and mid-dorsal parts lighter, greyyellowish. Dorsal pattern strongly contrasting (Figs 810): collum with a marbled yellow-brownish, oblong, central spot only slightly separated along lighter anterior and posterior margins, as well as from both lighter lateral ends; postcollum terga each with a light, sometimes vague, axial line broadening either into a subtriangular spot only at caudal margin or a horologiform spot broadened both caudally and anteriorly; a paramedian pair of large, light. transversely ovoid, dorsolateral, anterior spots (strongly marbled) and caudal bands (monochrome yellow-brown), on both sides reaching a broad lighter lateral margin. Anterior 2/3 and sides of tergum 2, as well as most of anal shield light (Figs 8-9). Venter and legs entirely light grey-yellow (Fig. 10).

Tergal tegument smooth and shining. Ocelli $7+1$, convex, completely translucent. Tömösváry's organ transverse-oval, ca 1.4 times wider than long. Antennomere 6 rather short, ca 2.1-2.2 times as long as high, dorsal margin as usual, only slightly concave (Fig. 10). Antennomere 8 with only four larger sensory cones. Collum with two transverse striae. Tergum 2 with a narrow hyposchism not reaching behind caudal tergal margin; 6-7 superficial transverse striae: three starting below schism, two level with, all others (1-2) above schism, with 3-4 crossing the dorsum. Anal shield regularly rounded at caudal margin.

$\sigma^{7}$ leg 17 (Fig. 11) strongly reduced, with a high, rather regularly rounded, outer coxal lobe; telopodite 4segmented, with only one strong apical spine.

$\sigma^{7}$ leg 18 (Fig. 12) less strongly reduced, with an ogival syncoxital notch; telopodite also 4-segmented, tarsus with one apical spine.

$\sigma^{7}$ legs 19, or telopods (Fig. 13), very strongly incrassate, with a relatively low, apically slightly concave, central, syncoxital lobe flanked by two densely setose horns, each latter nearly twice as high as syncoxital lobe and crowned by a very small, spiniform, acuminate filament. Prefemur anteriorly with a typically long trichostele distoventrally. Femur distoventrally with a small anterior trichostele and a large posterior outgrowth, the latter set at ca $120^{\circ}$ to femur and bearing a membranous apical sac slightly folded anteriad. Tibia distoventrally with a strong anterior seta/trichoid and a rather large posterior outgrowth, the latter bearing a distinct parabasal tubercle on caudal face. Tarsus rather strongly curved, subacuminate apically.

REMARK. This species has been referred to as Hyleoglomeris sp. in Golovatch et al. [2011].

ACKNOWLEDGEMENTS. Special thanks go to the Russia-Vietnam Joint Tropical Center for the support it rendered for our field research in Vietnam. Kirill Makarov very skillfully took all colour pictures. Both Kirill Mikhailov and Elena Kudryavtseva (ZMUM) helped us incorporate the ZMUM samples into the collection. 

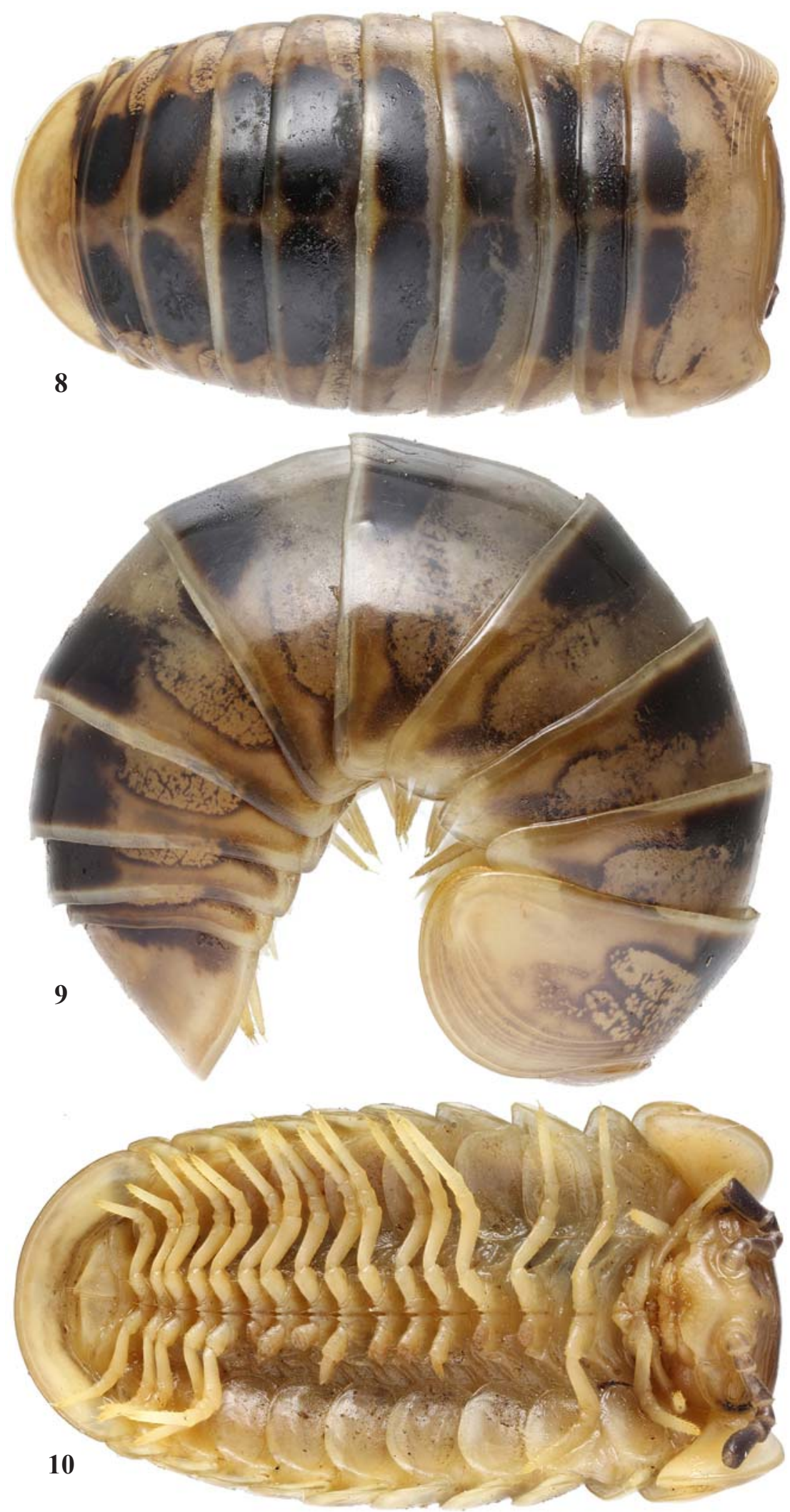

Figs 8-10. Habitus of Hyleoglomeris cattienensis sp.n., 9 paratype: 8 - dorsal view; 9 - lateral view; 10 - ventral view (most of the legs on the left side of the body cut off for chemical analyses). Pictures by K. Makarov, taken not to scale.

Рис. 8-10. Общий вид Hyleoglomeris cattienensis sp.n., паратип +: 8 - сверху; 9 - сбоку; 10 - снизу (большинство ног на левой стороне тела отрезаны для химических анализов). Фотографии К. Макарова, снято без масштаба. 


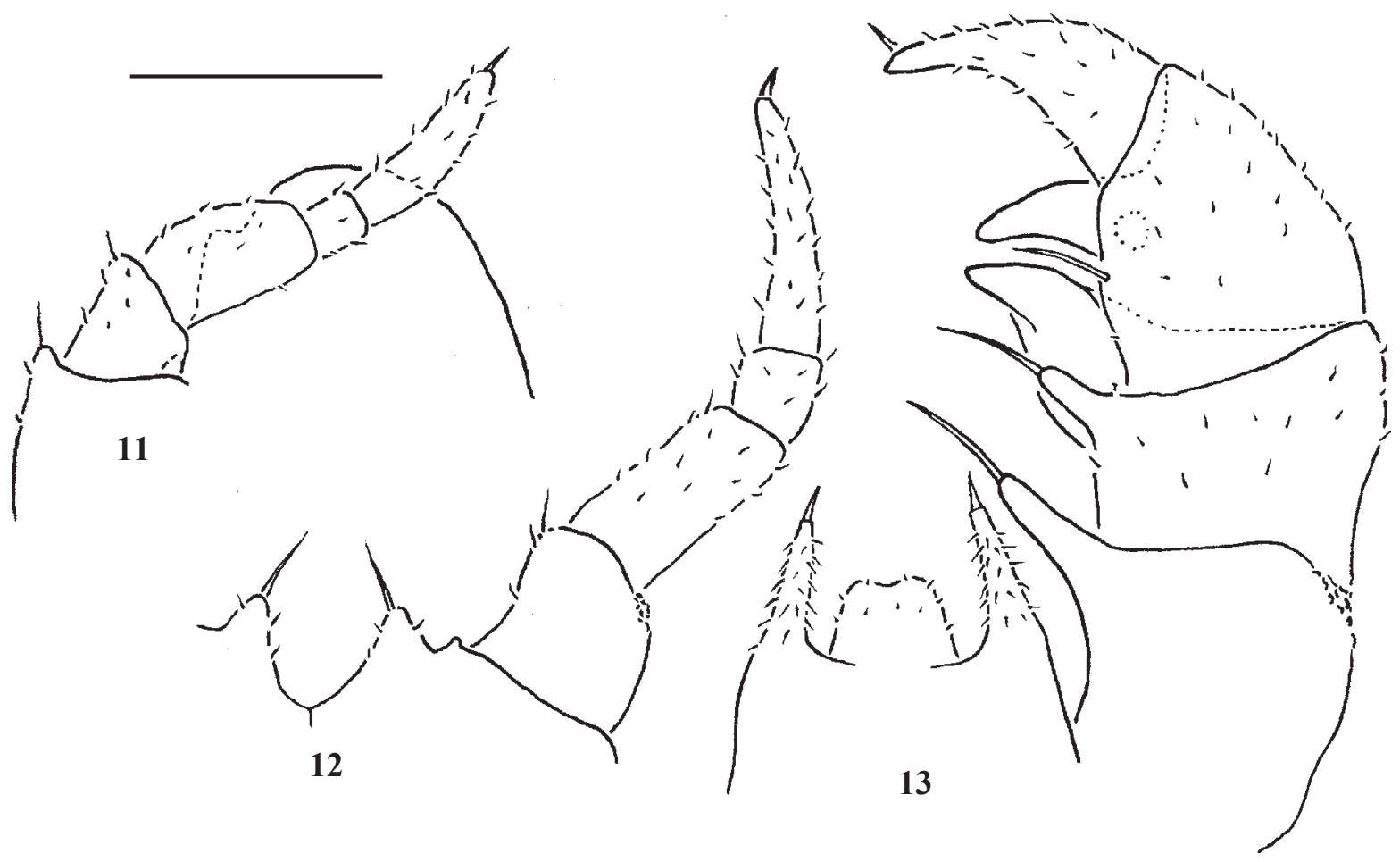

Figs 11-13. Hyleoglomeris cattienensis sp.n., $0^{7}$ holotype: 11 - left leg 17, caudal view; 12 - right leg 18, anterior view; 13 - right telopod, anterior view. Scale bar $0.5 \mathrm{~mm}$.

Рис. 11-13. Hyleoglomeris cattienensis sp.n., голотип О’: 11 - левая нога 17, сзади; 12 - правая нога 18, спереди; 13 - правый телопод, спереди. Масштаб 0,5 мм.

\section{References}

Attems C. 1938. Die von Dr C. Dawydoff in Französisch Indochina gesammelten Myriopoden // Mémoires du Muséum nationa d'Histoire naturelle, n.s. T.6. Fasc.2. P.187-353.

Golovatch S.I. 2015. A new species of the millipede genus Hyleoglomeris Verhoeff, 1910, from Tajikistan, Central Asia (Diplopoda: Glomerida: Glomeridae) // Russian Entomol. J. Vol.24. No.2. P.103-105.

Golovatch S.I., Geoffroy J.-J., Mauriès J.-P. 2006. Review of the millipede genus Hyleoglomeris Verhoeff, 1910 (Diplopoda, Glomerida, Glomeridae), with descriptions of new species from caves in Southeast Asia // Zoosystema. Vol.28. No.4. P.887-915.

Golovatch S.I., Geoffroy J.-J., VandenSpiegel D. 2013. On several new species of the millipede family Glomeridae from Vietnam (Diplopoda: Glomerida) // Arthropoda Selecta. Vol.22. No.3 P.201-206.
Golovatch S.I., Hoffman R.L., Chang H.W. 2011. Identity of Glomeris bicolor Wood, 1865, and the status of the generic names Hyleoglomeris Verhoeff, 1910 and Rhopalomeris Verhoeff, 1906 (Diplopoda, Glomeridae) // Tropical Natural History. Vol.11. No.1. P.1-8.

Golovatch S.I., Tiunov A.V., Anichkin A.E. 2011. [Millipedes (Diplopoda)] // Tiunov A.V. (ed.). [Structure and functions of soil communities of a monsoon tropical forest (Cat Tien National Park, southern Vietnam)]. Moscow: KMK Sci. Press. P.76-90 [in Russian, English summary].

Minelli A. (ed.). 2015. Treatise on Zoology - Anatomy, Taxonomy, Biology. The Myriapoda. Vol.2. Leiden-Boston: Brill. 482 p.

Silvestri F. 1917. Contributions to a knowledge of the Oriental Diplopoda Oniscomorpha. 1. The family Glomeridae // Records of the Indian Museum. Vol.13. P.103-151. 